\title{
Performansi Biologis Induk Bandeng (Chanos chanos forskall) Hasil Seleksi dalam Mendukung Domestikasi dan Pengembangan Budidaya di Tambak
}

\author{
Tony Setia Dharma ${ }^{1)^{*}}$, Gigih Setia Wibawa ${ }^{1)}$, A.A Kt. Alit ${ }^{1)}$, Gede S. Sumiarsa ${ }^{1)}$ \\ ${ }^{1)}$ Balai Besar Riset Budidaya Laut dan Penyuluhan Perikanan Gondol, Jl. Singaraja-Gilimanuk, Gerokgak, Buleleng, \\ Bali, Indonesia \\ ${ }^{*}$ Alamat korespondensi: tonysetiadharma@gmail.com
}

\begin{abstract}
ABSTRAK
Bandeng merupakan ikan yang memiliki rasa daging yang enak, harga relatif terjangkau oleh segala lapisan masyarakat dapat dibudidayakan secara polikultur dengan komoditas lainnya dan banyak petani yang melakukan usaha budidaya. Kendala di masyarakat bahwa pertumbuhan benih bandeng yang dihasilkan oleh pembenih memiliki variasi ukuran yang tinggi, dan pertumbuhan yang lambat di tambak. Tujuan dari penelitian adalah untuk mengetahui teknologi budidaya ikan bandeng, dan memperoleh data biologi induk bandeng G-1. Hewan uji yang digunakan adalah induk bandeng G-1. Penelitian dilakukan secara deskriptif, yaitu melakukan pengamatan secara fenotipik meliputi pertumbuhan setiap dua bulan sekali. Parameter yang diamati adalah beberapa aspek biologi bandeng hasil seleksi antara lain kualitas telur, sintasan, pertumbuhan, pengujian warna, kualitas daging, toleransi terhadap lingkungan, dan ketahanan terhadap penyakit. Hasil penelitian menunjukkan bahwa daya tetas telur berkisar 80-90,30\%, dan memiliki ketahanan larva (SAI) mencapai 4,0-4,6 hari setelah menetas. Kelangsungan hidup dan pertumbuhan benih G-2 pada pembenihan umur 14-16 hari (SR) mencapai 60-85\%, panjang total (TL) 1,68$1,72 \mathrm{~cm}$, Warna induk bandeng dan ukuran konsumsi dengan menggunakan adalah hijau pada nomor TC.4408 dan perak TC.5501. Kualitas daging dari bandeng G-1 memiliki nilai 8. Kadar histamin untuk semua lokasi budidaya ND (non-detections). Toleransi benih terhadap lingkungan, ikan bandeng memiliki ketahanan terhadap salinitas 0-45 ppt, suhu $20-40^{\circ} \mathrm{C}$, pH 6-9, dan oksigen lebih dari $2 \mathrm{ppm}$, kemudian memiliki ketahanan terhadap penyakit.
\end{abstract}

Kata kunci: induk bandeng, performansi biologi, kualitas daging, toleransi benih

\section{The Biological Performances of Milkfish (Chanos-Chanos forskall) for Supporting of Domestication and Development of Aquaculture in Fishpond}

\author{
Tony Setia Dharma ${ }^{1)^{*}}$, Gigih Setia Wibawa ${ }^{1)}$, A.A Kt. Alit ${ }^{1)}$, Gede S. Sumiarsa ${ }^{1)}$ \\ ${ }^{1)}$ Center for Marine Aquaculture Research and Fisheries Counseling Gondol, Jl. Singaraja-Gilimanuk, Gerokgak, \\ Buleleng, Bali, Indonesia \\ *Email : tonysetiadharma@gmail.com
}

\begin{abstract}
Milkfish is a fish that has a good taste of meat, relatively affordable prices by all walks of life can be cultivated in polyculture with other commodities and many farmers who carry out cultivation. Constraints in the community that the growth of milkfish seeds produced by hatchers has a high size variation, and slow growth in ponds. The purpose of the study was to determine the technology of milkfish cultivation and to obtain data on the biology of milkfish G-1. The test animal used is G-1 milkfish broodstock. The study was carried out in a descriptive, which was to conduct phenotypic observations including growth every two months. The parameters observed were several aspects of the milkfish biology that were selected, including egg quality, survival, growth, color testing, meat quality, environmental tolerance, and disease resistance. The results showed that the hatchability of eggs ranged from $80-90.30 \%$, and had resistance to larvae (SAI) reaching 4.0-4.6 days after hatching. The survival and growth of G-2 seeds at seeding age of 14-16 days (SR) reached $60-85 \%$, total length (TL) of $1.68-1.72 \mathrm{~cm}$, color of milkfish broodstock and size of consumption using green number TC.4408 and silver TC.5501. The quality of meat from milkfish G-1 has a value of 8 . Histamine levels for all ND cultivation locations (non-detections). Seed tolerance to the environment, milkfish
\end{abstract}


has resistance to salinity $0-45 \mathrm{ppt}$, temperature $20-40{ }^{\circ} \mathrm{C}, \mathrm{pH}$ 6-9 and oxygen $>2 \mathrm{ppm}$, then has resistance to disease.

Keywords: milkfish broodstock, biological performance, meat quality, seed tolerance

\section{PENDAHULUAN}

Bandeng merupakan komoditas ikan yang memiliki nilai ekonomis. Setiap tahun permintaan bandeng selalu mengalami peningkatan, baik untuk konsumsi local, sebagai umpan hidup bagi usaha penangkapan ikan tuna, untuk keperluan indukan, maupun pemenuhan kebutuhan ekspor. Kebutuhan bandeng untuk ekspor cenderung meningkat sehingga merupakan peluang usaha yang positif. Ikan bandeng merupakan komoditas budidaya penting karena memiliki rasa daging yang enak, harga relative terjangkau oleh segala lapisan masyarakat, tahan terhadap serangan penyakit, tidak bersifat kanibal sehingga dapat hidup pada kepadatan yang tinggi, dapat dibudidayakan secara polikultur dengan komoditas lainnya sehingga banyak petani yang melakukan usaha budidaya [1].

Meningkatnya permintaan benih bandeng untuk pasar domestik sangat tinggi serta adanya export ke beberapa negara meningkat, maka kualitas benih bandeng produksi hatchery skala rumah tangga harus diperhatikan terutama managemen pakan dan lingkungan yang terkontrol, agar kualitas benih dan gelondonan yang dihasilkan memenuhi standar ekspor. Induk bandeng sebagai inti untuk memproduksi benih perlu mendapatkan perhatian dalam penanganan, mulai seleksi individu bandeng yang baik hingga pemilihan benih, cara pembesaran dan media air pemeliharan yang baik hingga dapat menghasilkan benih dan gelondongan yang tumbah cepat secara berkelanjutan. Selain sebagai ikan konsumsi, ikan bandeng pada tahun-tahun terakhir ini banyak diminta sebagai ikan umpan hidup untuk usaha penangkapan ikan tuna (Thunnus sp) dan cakalang (Katsuwonus pelamis). Secara taksonomis, ikan bandeng termasuk dalam kelas Pices, subkelas Teleostei, Ordo Malacopterygii, famili Chanidae, genus Chanos, dan spesies Chanos chanos (forskall). Nama lain dari ikan bandeng dikenal bolu, muloh, dan ikan agam, atau milkfish dalam bahasa Inggris. Ikan bandeng termasuk ikan laut, namun dapat juga hidup di air payau dan air tawar, mampu beradaptasi pada perubahan kadar garam yang sangat besar atau bersifat eurihalin. Balai Besar Penelitian dan Pengembangan Budidaya Laut (BBPPBL) telah berhasil melakukan domestikasi dan produksi bandeng skala masal di hatchery dengan fluktuasi sintasan benih yang berumur 16-17 hari berkisar 80-92 \% dan pada pendederan bandeng sesuai SOP dapat meningkatkan sintasan yang mana dari sintasan sebelumnya sebesar $30-50 \%$ meningkat menjadi sekitar 65-80\%. Waktu yang diperlukan untuk kegiatan pendederan juga menjadi lebih singkat 1 bulan untuk mencapai ukuran 10-12 cm, yaitu dari empat bulan menjadi tiga bulan [2]. Benih hasil pembenihan di hatchery juga telah didederkan dengan pemberian pakan buatan [2] dan telah berhasil hingga mencapai ukuran konsumsi [3].

Domestikasi adalah suatu proses adaptasi pada lingkungan budidaya dari generasi ke generasi. Domestikasi merupakan salah satu langkah kearah pengembang biakan yang meliputi aspek eksplorasi, koleksi, dokumentasi, karakterisasi dan penguasaan teknologi pembenihan secara alami dan buatan serta pembesarannya. Penguasaan teknologi perbenihan meliputi: pematangan gonad, pemijahan, perawatan telur dan larva dilanjutkan perawatan benih dan penanggulangan penyakit. Penguasaan domestikasi dapat mendukung ketersediaan ikan konsumsi dari produksi berbasis budidaya yang aman dari kelangkaan dan lestari di alam. Kegiatan penelitian ini dilakukan dalam rangka memperoleh data biologi ikan bandeng untuk mendukung domestikasi bandeng.

\section{METODE PENELITIAN}

Penelitian ini dilakukan dengan cara deskriptif, mengamati induk bandeng G-1 dan telur yang dihasillkan serta benih G-2 di bak dan tambak. Wadah yang digunakan adalah bak beton sebanyak dua buah dengan volume $150 \mathrm{~m}^{3}$. Ikan uji dalam penelitian ini adalah induk bandeng hasil seleksi asal bak beton B1 dan B2 diseleksi dengan ratio jenis kelamin jantan dan betina 1:2 dengan bobot 5,50-6,50 $\mathrm{kg}$. Induk dipelihara pada kondisi lingkungan yang baik dengan kepadatan pada bak B masing-masing sebanyak 55 ekor/bak. Jenis pakan yang diberikan pelet komersial dengan 
kadar protein sekitar $44 \%$ untuk meningkatkan kualitas dari pakan ditambahkan vitamin E,C, minyak ikan nabati dan kuning telur/lecitin. Frekuensi pemberian pakan 3 kali perhari yaitu pada pagi, siang dan sore sebanyak $3 \%$ /hari. Telur yang dihasilkan dipelihara dalam bak larva dengan penerapan CPIB hingga menghasilkan benih G-2. Parameter yang diamati adalah beberapa aspek biologi bandeng hasil seleksi antara lain kualitas telur, sintasan, pertumbuhan, pengujian warna, kualitas daging, toleransi terhadap lingkungan, dan ketahanan terhadap penyakit.

\section{HASIL DAN PEMBAHASAN}

Hasil penelitian menunjukkan bahwa performa biologi induk G-1 meliputi Kelangsungan hidup, pertumbuhan, pengujian warna, nilai toleransi lingkungan dan ketahanan penyakit adalah pada Tabel 1 dan 2 .

Tabel 1. Hasil pengamatan kualitas telur induk bandeng (Chanos chanos) G-1 pada pemeliharaan secara terkontrol

\begin{tabular}{lllll}
\hline \multicolumn{4}{c}{ Performansi kualitas telur } \\
\hline Siklus & $\begin{array}{l}\text { Jumlah } \\
\text { telur } \\
\text { (pc) }\end{array}$ & $\begin{array}{l}\text { Telur } \\
\text { dibuahi } \\
(\%)\end{array}$ & $\begin{array}{l}\text { Daya } \\
\text { tetas } \\
(\%)\end{array}$ & $\begin{array}{l}\text { Daya } \\
\text { tahan } \\
\text { larva } \\
\text { setelah } \\
\text { menetas } \\
\text { (hari) }\end{array}$ \\
\hline 1 & & & & 4 \\
2 & 100.000 & 92 & 88 & 4 \\
3 & 100.000 & 90 & 82 & 4 \\
\hline
\end{tabular}

Tabel 2. Hasil pengamatan kelangsungan hidup, pertumbuhan benih bandeng (Chanos chanos) pada pemeliharaan secara terkontrol

\begin{tabular}{lllll}
\hline Siklus & $\begin{array}{l}\text { Kelangs } \\
\text { ungan } \\
\text { hidup } \\
\mathbf{( \% )}\end{array}$ & $\begin{array}{l}\text { Panjang } \\
\text { total } \\
\mathbf{( c m )}\end{array}$ & $\begin{array}{l}\text { Bobot } \\
\text { tubuh } \\
\mathbf{( g )}\end{array}$ & $\begin{array}{l}\text { Umur } \\
\text { panen }\end{array}$ \\
\hline 1 & 55,80 & 1,68 & $1,3 \times 10^{-3}$ & 16 \\
2 & 59,50 & 1,72 & $1,4 \times 10^{-3}$ & 16 \\
3 & 85,00 & 1,69 & $1,4 \times 10^{-3}$ & 17 \\
\hline
\end{tabular}

Pengujian warna. Hasil pengujian warna dilakukan pada bandeng ukuran konsumsi dan calon induk dengan menggunakan alat Tocca Colour. Hasilnya adalah hijau TC.4008 dan perak TC.5501.
Bandeng konsumsi terlihat warna kehijauan dan calon induk warna keperakan.

Kualitas daging. Dari hasil uji organoleptik bahwa tingkat kesegaran kualitas daging ikan bandeng G-2 tingkat kesegarannya sama memiliki nilai 7 , sedangkan uji secara organoleptik bandeng G-2 lebih tinggi yaitu memiliki nilai 8 dan asal Lamongan dan Sidoardjo memiliki nilai 7. Kadar histamin untuk semua lokasi budidaya ND (nondetections).

Toleransi terhadap lingkungan. Hasil uji toleransi benih, ikan bandeng memiliki ketahanan terhadap salinitas $0-45 \mathrm{ppt}$, suhu 20$40^{\circ} \mathrm{C}$, pH 6-9 dan oksigen $>2 \mathrm{ppm}$. Sintasan yang dihasilkan adalah pada Tabel 3 .

Tabel 3. Hasil pengamatan pada uji toleransi benih G-2 pada salinitas, suhu, $\mathrm{pH}$ dan oksigen

\begin{tabular}{llc}
\hline No & Parameter & Kelangsungan hidup (\%) \\
\hline 1 & $\begin{array}{l}\text { Salinitas } \\
(0-45 \mathrm{ppt})\end{array}$ & $94,03 \pm 2,67-99,12 \pm 0,67$ \\
2 & $\begin{array}{l}\text { Suhu } \\
(20-45 \mathrm{C})\end{array}$ & $50,50 \pm 0,30-98,46 \pm 0,69$ \\
3 & $\begin{array}{l}\mathrm{pH} \\
(6-9)\end{array}$ & $50,10 \pm 0,34-90,60 \pm 1,34$ \\
4 & $\begin{array}{l}\text { Oksigen } \\
(>2 \mathrm{ppm})\end{array}$ & $51,20 \pm 0,73-95,80 \pm 1,03$ \\
\hline
\end{tabular}

Ketahanan penyakit. Bandeng telah dikenal tahan terhadap penyakit. Hal ini terlihat pada uji tantang terhadap penyakit bacterial Vibrio sp pada bandeng bahwa bandeng tersebut masih mampu bertahan untuk hidup. Pada benih bandeng umur 14-16 hari dengan ukuran 1,4-1,6 cm bahwa tahan terhadap Vibrio sp sampai dengan kepadatan $10^{9} \mathrm{CFU} / \mathrm{mL}$.

Hasil penelitian menunjukkan bahwa performa biologi dari induk G-1 meliputi kelangsungan hidup, pertumbuhan, pengujian warna, nilai toleransi lingkungan dan ketahanan penyakit masih berada dalam kisaran yang normal dan sesuai dengan biologi ikan bandeng. Pengamatan kualitas air selama percobaan menunjukkan bahwa selama masa pemeliharaan induk ikan bandeng di bak beton, kualitas air masih berada dalam kisaran yang aman. Hal ini sesuai dengan hasil pengamatan $[1,3,4]$ yaitu kisaran kualitas air dari masing-masing perlakuan relatif sama dan masih dalam batas yang normal untuk kehidupan induk karena jumlah pergantian air selama pemeliharaan dalam 24 jam lebih dari $200 \%$. Nilai kisaran 
tersebut masih terjaga dengan baik karena selalu dilakukan kontrol pergantian air dan penyiponan dasar bak. Hal ini dilakukan untuk menjaga agar tidak terjadi akumulasi sisa pakan yang dapat menghambat pertumbuhan dari calon induk ikan. Salinitas merupakan salah satu faktor abiotik penting yang mempengaruhi sintasan organisme akuatik. Oleh sebab itu, perlunya penentuan salinitas optimum bagi gelondongan bandeng agar sesuai dengan kebutuhannya untuk mempertahankan sintasannya. Kebutuhan salinitas optimum pada setiap organisme perairan berbeda-beda seperti yang didapatkan pada benih bandeng yang optimum pada salinitas 40 ppt $[5,6,7]$. Ikan bandeng pada salinitas 0-45 ppt namun salinitas optimun 15-18 ppt [8,9]. Suhu merupakan salah satu faktor yang penting di dalam kegiatan budidaya perikanan. Suatu aktivitas metabolisme ikan berbanding lurus terhadap suhu air. Semakin tinggi suhu air semakin aktif pula metabolisme ikan, demikian pula sebaliknya $[10,11]$. Kondisi suhu sangat berpengaruh terhadap kehidupan ikan. Nilai optimum suhu untuk budidaya bandeng 26$32^{\circ} \mathrm{C}$ [9]. Derajat keasaman $(\mathrm{pH})$ sangat penting sebagai parameter kualitas air karena merupakan kontrol tipe dan laju reaksi beberapa bahan dalam air, tidak semua mahkluk hidup bisa bertahan dengan perubahan nilai $\mathrm{pH}$, untuk itu alam telah menyediakan mekanisme yang unik agar perubahan tidak terjadi atau terjadi tetapi dengan cara perlahan. $\mathrm{pH}$ adalah suatu ukuran dari konsentrasi ion hydrogen dan menunjukkan suatu perairan apakah bersifat asam atau basa. Sesuai dengan pernyataan [10] bahwa $\mathrm{pH}$ yang didefinisikan sebagai logaritma negatif dari konsentrasi ion Hidrogen $\left(\mathrm{H}^{+}\right)$yang merupakan indikator keasaman serta kebasaan air. Kemudian $\mathrm{pH}$ yang baik untuk kehidupan ikan berkisar antara 6,5-8,5. pH air berkisar 4,0-6,5 menyebabkan pertumbuhan ikan menjadi lambat, sedangkan pH di bawah empat dan diatas 11 merupakan titik asam dan alkali yang mematikan. Kadar oksigen yang terlarut dalam air dalam menunjang kehidupan organisma di dalam air yaitu minimal 2 ppm, jika oksigen terlarut dalam air menurun, mengakibatkan gerakan ikan lambat dan tidak lincah serta hampir semua organisma akan bergerak ke atas permukaan air. Untuk memenuhi kebutuhan oksigen pada ikan tersebut biasanya diusahakan dengan melakukan pergantian air yang seimbang sehingga kondisi kualitas air stabil. Oksigen juga merupakan salah satu faktor pembatas. Sesuai dengan pernyataan [11] bahwa nilai DO pada perairan laut yang ideal adalah sekitar $\pm 7 \mathrm{mg} / \mathrm{L}$. Bandeng tahan terhadap penyakit. Pada uji tantang penyakit bacterial Vibrio pada bandeng dari spesies Vibrio alginolyticus, $V$ harveyi, dan $V$ parahaemolyticus. Menurut [12] diketahui bahwa ketiga jenis bakteri tersebut tidak patogen bagi bandeng dari kepadatan $10^{5}$ $\mathrm{CFU} / \mathrm{mL}$ hingga $10^{9} \mathrm{CFU} / \mathrm{mL}$. Untuk konfirmasi ada atau tidak adanya sifat patogen dari bakteri Vibrio, maka dilakukan uji patogenisitas isolat Vibrio harveyi terhadap larva bandeng.

\section{KESIMPULAN}

Performa biologi induk bandeng G-1 adalah memiliki daya tetas telur berkisar 80 $90,30 \%$, ketahanan larva (SAI) mencapai 4,04,6 hari setelah menetas. Sintasan dan pertumbuhan benih yang dihasilkan mencapai $60-85 \%$, panjang total (TL) $1,68-1,72 \mathrm{~cm}$ selama 14-16 hari. Warna dari induk bandeng dan ukuran konsumsi adalah hijau pada nomer TC.4408 dan perak TC.5501. Kualitas daging memiliki nilai 8 . Kadar histamin untuk semua lokasi budidaya ND (non-detections). Toleransi benih terhadap lingkungan, ikan bandeng memiliki ketahanan terhadap salinitas 0-45 ppt, suhu $20-40^{\circ} \mathrm{C}, \mathrm{pH}$ 6-9 dan oksigen $>2 \mathrm{ppm}$,

kemudian memiliki ketahanan terhadap penyakit.

\section{UCAPAN TERIMA KASIH}

Penulis mengucapkan terimakasih kepada segala pihak yang membantu selama penelitian berlangsung.

\section{DAFTAR PUSTAKA}

[1] Sudradjat A (2011) Panen bandeng 50 hari. Penebar Swadaya, Jakarta.

[2] Setiadharma T, Setiadi I, Wibawa SW (2014) Pengelolaan induk bandeng, Chanos chanos forskall hasil seleksi. Laporan teknis akhir kegiatan. Balai besar penelitian dan pengembangan budidaya laut. Badan penelitian dan pengembangan kelautan dan perikanan. Kementerian Kelautan dan Perikanan, Jakarta.

[3] Setiadharma T, Alit AAK, Priyono A, Wibawa GS (2012) Performa benih ikan bandeng (Chanos chanos Forsskall) 
pada pembesaran di bak dan hafa di tambak dengan perbedaan kepadatan. BBPPBL. Laporan Hasil Penelitian.

[4] Sudradjat A, Wedjatmiko, Tony S (2011) Budidaya ikan bandeng (Chanos chanos Forsskal). Balai Besar Penelitian dan Pengembangan Budidaya Laut. Badan Penelitian dan Pengembangan Kelautan dan Perikanan. Kementerian Kelautan dan Perikanan. ISBN: 978979-786-038-7.

[5] Imsland AK, Gústavsson A, Gunnarsson S, Foss A, Árnason J, Arnarson I, Jónsson AF, Smáradóttir H, Thorarensen H (2008) Effects of reduced salinities on growth, feed conversion efficiency and blood physiology of juvenile atlantic halibut (Hippoglossus hippoglossus L). Aquaculture 274: 254-259.

[6] Praseno O, Krettiawan H, Asih S, Sudrajdat A (2010) Uji ketahanan salinitas beberapa strain ikan Mas yang dipelihara di akuarium. Prosiding Forum Inovasi Teknologi Akuakultur.

[7] Priyono A, Aslianti T, Setiadharma T, Giri INA (2011) Petunjuk teknis perbenihan ikan Bandeng (Chanos chanos Forsskal). Balai Besar Penelitian dan Pengembangan Budidaya Laut. Badan Penelitian dan Pengembangan Kelautan dan Perikanan. Kementerian Kelautan dan Perikanan. ISBN: 978979-17440-6-5.

[8] Sumawidjaja K, Yusdiana T, Effendi E, Dharmadi (2002) Pembesaran ikan Bandeng, Chanos chanos, dalam karamba jaring apung di laut pada berbagai padat penebaran. Jurnal Akuakultur Indonesia 1 (2): 53-55.

[9] Ahmad T, Ratnawati E, Yakob JR (1999) Budidaya Bandeng secara intensif. Penebar Swadaya, Yogyakarta.

[10] Boyd, C.E. 1990. Water Quality in ponds for aquaculture. Birmingham Publishing Co. Alabama: Auburn University. p. 482.

[11] Dewi, ES (2006) Pengaruh salinitas 0, 3, 6 , dan 12 terhadap pertumbuhan dan kelangsungan hidup benih ikan Gurame (Osprhonemus gouramy) ukuran 3-6 cm. Skripsi. Departemen Budidaya Perairan, Fakultas Perikanan dan Ilmu Kelautan, Institut Pertanian Bogor.

[12] Anonym (2016) Dokumen rilis ikan Bandeng (Chanos chanos Forskall). BBRBLPP. Badan Riset dan Sumber
Daya Manusia Kelautan dan Perikanan. Kementerian Kelautan dan Perikanan. 